\title{
«A culture of War and a Culture of Exile»
}

Young Eritreans in Germany and their Relations to Eritrea

"Culture de guerre et culture d'exil ». Les jeunes Érythréens d'Allemagne et leurs relations à l'Érythrée

"Cultura de guerra y cultura de exilio». Los jóvenes eritreos de Alemania y sus

relaciones con Eritrea

\section{Bettina Conrad}

\section{CpenEdition}

\section{Journals}

Electronic version

URL: https://journals.openedition.org/remi/2712

DOI: $10.4000 /$ remi.2712

ISSN: $1777-5418$

Publisher

Université de Poitiers

Printed version

Date of publication: 1 March 2006

Number of pages: $59-85$

ISBN: 2-911627-41-5

ISSN: 0765-0752

\section{Electronic reference}

Bettina Conrad, " A culture of War and a Culture of Exile»", Revue européenne des migrations

internationales [Online], vol. 22 - $n^{\circ} 1 \mid$ 2006, Online since 01 avril 2009, connection on 28 juin 2022.

URL: http://journals.openedition.org/remi/2712 ; DOI: https://doi.org/10.4000/remi.2712

This text was automatically generated on 14 April 2022.

(C) Université de Poitiers 


\title{
«A culture of War and a Culture of Exile»
}

\author{
Young Eritreans in Germany and their Relations to Eritrea \\ "Culture de guerre et culture d'exil ». Les jeunes Érythréens d'Allemagne et \\ leurs relations à l'Érythrée \\ «Cultura de guerra y cultura de exilio». Los jóvenes eritreos de Alemania y sus \\ relaciones con Eritrea
}

Bettina Conrad

\section{AUTHOR'S NOTE}

The phrasing of the title "A Culture of War and a Culture of Exile" is borrowed from a text by Naila Habib (1996: 97).

\section{Introduction: a homecoming}

1 In the course of the 30-year war for independence from Ethiopia hundreds of thousands Eritreans were forced to leave their country. Today an estimated third of all Eritreans live scattered across Northeast Africa, the Middle East, North America, Australia and Europe. Most of the 25,000 Eritreans living in Germany today arrived as refugees in the mid- and late 1970s and throughout the 1980s (cf. Schröder 2004). ${ }^{1}$ In their vast majority they supported the independence struggle waged by Eritrean People's Liberation Front (EPLF) and dreamt of a return to their home country. By the time Eritrea was liberated (May 1991) and gained formal independence (May 1993), many exiles had been abroad for more than a decade. Returning home, though finally feasible, proved to be more difficult than anticipated. The situation of second generation or those born or raised in exile led Eritrean parents in Germany to postpone repatriation plans into the indefinite future. Among other reasons, parents were 
concerned about interrupting the education of their children and opted to wait until their children have finished school, or other educational persuits and were independent.

But even these however vague plans where shattered in May 1998 as an unexpected war broke out between independent Eritrea and Ethiopia, ultimately costing both countries tens of thousands of lives and millions of livelihoods. Though patriotic feelings were running high, and diaspora Eritreans contributed large sums for both the military defense and post-war reconstruction efforts, the idea of starting a new life in Eritrea seemed more illusionary than ever. When the military conflict ended in an unstable peace in 2000 , it left the country economically devastated and - worst of all bereft of the can-do-optimism that had characterized the immediate postindependence period. Moreover, after the (1998-2000) war, the once internationally praised Eritrean government became increasingly repressive. ${ }^{2}$ It is hardly surprising that most diaspora Eritreans that were still hoping to return have suspended their plans and instead have settled for annual or biannual "pilgrimages" to their place of origin. They come to meet their families and old friends, to take a break fro the pressures of an often marginalised existence in their host society and also to introduce their diaspora - raised children to their Eritran relatives, and their cultural roots. It is these (first) ambiguous encounters of young diaspora Eritreans with their parents' home country, that this paper focuses on.

3 Most of the empirical data presented here were gathered between 1999 and 2004 as part of a larger study on the Eritrean diaspora in Germany. A first fieldwork phase in, included participant observation of various meetings, open interviews with members of Eritrean youth groups, political cadres and social workers as well as a small scale survey among Eritrean youth. During a second fieldwork phase in Eritrea (summer 2001), again participant observation as well as formal and informal conversations provided the main methods for soliciting data. In a third phase individuals and groups were interviewed about their experiences in Eritrea after their return to Germany (2002-2004). Particularly insightful was an organised journey to various places throughout the country together with group of young diaspora Eritreans. I use my fieldnotes of this trip as a starting point for further analysis: ${ }^{3}$

4 It's the third day of the Zura Hagerka, or "Know-Your-Country-Tour." The bus carries about 50 young diaspora Eritreans and one ferenji up a winding mountain pass. Having escaped the suffocating heat of the Red Sea port Massawa, spirits are rising as we head for Adi Keyh, a small town on the Eritrean highland plateau. My fellow passengers are dressed in fashionable western style and equipped with digital cameras. They joke, curse and gossip in Swedish, Dutch, British and American English, Italian or German interspersed with the local Tigrinya in varying degrees of fluency ${ }^{4}$. But right now it is too loud to talk much in whatever language. Traditional gwayla music played at high decibels fills the vehicle. It is accompanied by spontaneous outbursts of sing-along and clapping, especially when some old revolutionary song sets in. Like on a schooltrip, the atmosphere is charged with excitement and a shared determination to have fun. But my travel compagnions also celebrate their Eritrean-ness that is not recognized wherever they have settled in the diaspora.

5 When we reach Adi Keyh night has fallen.... The town has few tarmac roads and our bus bumps awkwardly through the potholes before stopping in front of a three-storey building. Its walled compound harbours a simple hotel and a day time cafe. The room I share with Harnet from Germany and Selamawit from Sweden is damp and sparsely furnished. We drop our luggage into 
a corner and try to wash off the grimy layers of sweat and dust. There is no time for more elaborate styling. The local branch of the National Union of Eritrean Youth and Students has invited the guests for a dance party. It takes place in a hall some 100 metres down the road. When we arrive there, women ululate at the entrance and throw popcorn for a traditional welcome. We are offered freshly brewed tea, coffee and himbasha, a delicious homemade bread. The otherwise dismal looking room is decorated with a banner reading "Welcome" in various languages. In the rear red plastic folding chairs have been arranged in two neat blocks of rows. They face a stage at the front of the hall where a band is getting ready to play. We are ushered into one block of seats and urged to have more tea and bread. The other half of the room gradually fills with locals - mostly boys and young men between thirteen and eighteen, a reminder that most of the $18+$ generation are still serving in the army. Only a year ago Eritrea was at war with Ethiopia. Even now peace is fragile. Adi Keyh is not far from the contested border area. Very likely most of these youngsters that are now staring at us with a mixture of curiosity and suspicion have a bother or sister in the trenches.

6 After the official welcome the band starts playing. We duly clap our hands, but the clapping seems more restrained than earlier on the bus. Suddenly a young man of about 17 jumps out of nowhere onto the open space between stage and audience. He moves wildly, exaltedly, tries a breakdance element, stumbles, his limbs jerking grotesquely in mid air. But this is not some humourous stunt. Something is wrong with the guy. Two locals try to haul him off the dance floor, but he paddles free and only slouches off with a dazed look into the crowd once the music stops. When the band plays the next piece everyone gets up to dance, but the atmosphere remains tense. The third dance is for me. This time three young "misfits" occupy the floor, and one of them has sought me out as his dancing partner. He gestures me to join him, then moves closer, takes my hand and pulls me onto the dancefloor... There's nothing for it. For a while the three guys and I remain the lonely entertainers of an awkward audience. Eventually some of the onlookers join in. I manage to retreat to a chair in the backrow where Harnet approaches me with a worried look: "Let's go back to the hotel," she says. "This is no fun. Selamawit has already left."

7 But as we are leaving the hall, our roommate is coming back in. She is upset and angry. On her way she had run into a drunk elderly man. Brandishing his walking stick he had shouted at her: "I'll beat you, I'll kill you ...." She fled to the hotel, but found the front door locked. Some soldiers offered to show her the back entrance, but then tried to lure her into the wrong direction. Finally a passerby who "rescued" her expected to be taken to her room as a "thank you". Unable to shake him off, she decided to return to the crowd... Now as we are walking back together the street is empty and eerily quiet. Selamawit leads the way around the hotel where a huge iron gate opens into the yard. She is still contagiously nervous. We chat for a while, but as we are getting ready for bed a tumult raises outside. From a balcony overlooking the dimly lit courtyard we see Fiori running through the gate, screaming. She is followed by a group of people. For a splitsecond I think it's some locals chasing her, but then I recognise other tour members. One of them slams the gate shut crying in German: "Come here! Help me!" Two guys hold fast against the gate while Yonas bolts it. The next moment a cascade of stones and furious voices hit the corrugated iron sheets from the other side.

8 After some frantic counting of heads it is established that we are complete.... Provided with tea "on the house" and huddled around two tables in the closed café some of the group try to reconstruct the happenings: Some time after Harnet, Selamawit and myself had left, the other Know-Your-Country-Tourers also decided to go. Outside the hall another group of local youth had gathered and tried to provoke the departing guests with insults. When one of them grabbed 
at a girl from Sweden, she said something rude to him. He spat at her in reply wherupon she slapped him squarely in the face. Others intervened and the situation threatend to escalate into a fight. Within the diaspora group someone had the good sense to call for a retreat. Yet when they turned to go, the locals began throwing fist-sized stones at them. They panicked and ran away, the locals at their heels.

(...) Though no one got hurt, the shock is profund. Sara and Almaz look wide-eyed and scared. Bereket is simply bewildered. This is his first visit in eleven years and so much has changed. Yonas mutters to himself in German that he'll take the next plane back home - to Frankfurt. Sam shruggs: "... can happen anywhere." Paulos shakes his head violently: "But we are not anywhere! I thought Eritrea was the place where I belong! This is like running away from the Neonazis in Frankfurt." - "Worse!" Yonas exclaims, "At least there are no stones in Frankfurt!" The laughter that follows releases some of the tension. It also makes Harnet emerge from a long silence. She straightens up to declare defiantly: "This will bring us only closer together." At this moment, her appeal to group solidarity even includes me, the ferenji. But at the same time the "us" separates the diaspora Eritreans from "them," the local Eritreans outside. Perhaps that's also what Henok feels when he says: "We aren't Eritreans anymore."

\section{Long-distance nationalism, diaspora and the dilemmas of the second generation}

10 The above thick description captures one of the dark moments of the transnational experience; the realisation, that being at home here and there, can also turn into being at home neither here nor there. It further introduces the main characters of this paper: second and 1.5 generation Eritreans living in the diaspora in Germany. ${ }^{5}$ Taking this confrontation between the local Eritrean youth and their peers that have grown up abroad as a point of departure, I want to analyse the ambiguous and conflicting relationship between a "culture of war" and a "culture of exile," that - while fighting for a common cause and inhabiting a single transnational space - have inevitably grown apart in many respects.

11 It was the dream of an independent nation that drove Eritreans into exile. It was (longdistance) nationalism (Anderson 1992, Glick-Schiller and Fouron 2001) that continued to shape their individual lives and the communities they built abroad and that sustained their hope of returning. Yet, it is the diaspora where most of them seem to have arrived today. ${ }^{6}$ At least if we apply Cohen and Safrans' much cited set of features that characterise a diaspora (Cohen 1997: 26, after Safran 1991), Eritreans in Germany may well be labelled a diaspora. Until recently, however, "diaspora" was not an - emic term, and even today many Eritreans prefer to speak about the Eritrean "community," a term used in a highly fexible manner.7 It may refer to the members of particular local community association as well as to the totality of all Eritreans living in a certain town, region, or country - or even worldwide. The term "community" has also often been specified by adding "refugee" or "exile" to it, thus drawing a sharp distincton between themselves and labour migrants. This again reflects their strong emphasis on the forced nature of their immigration, and highlights long-distance nationalism and the myth of return as the community's most outstanding features.

12 I have argued elsewhere that until independence, Eritreans in Germany were most aptly characterised by calling them an "exile community" whose focus was almost 
solely directed towards home and the involvement in an ongoing nation-building project (Conrad 2003, 2005). Until 1991 they were methaphorically speaking "sitting on packed suitcases". Their sojourn, no matter for how long it had lasted, was perceived as only temporary - a notion that was very much in line with the German hosts (and the Eritrean liberation movements), who also regarded refugees and "guestworkers", as birds of passages that should not remain for good. In this regard, one diaspora characteristic listed by Cohen was almost completely absent during the Eritrean liberation struggle: “... the possibilty of a distinctive, creative, enriching life in host countries..." (Cohen 1997: 26). Paradoxically it was only after the successful war for Eritrean independence (1962-1991) that a more permanent settlement in Germany also began to be considered as an alternative to return - even if only for an intermediate, undefined period of time. Choosing this option, however, forced exile Eritreans to redefine their relationships with both home and host country, and literally re-form their organisations to make them suit their changed needs. These changes, which set in with the event of independence, so I argue, can also be described as a transformation process from exile to diaspora, from a provisonal to a more settled immigrant community, from birds of passage to "strangers who come today, and stay tomorrow" as Georg Simmel (1968: 509) once put it. ${ }^{8}$ Moreover this development coincided with, and was accelerated by, the maturing of a second generation that only knew life in Germany.

Another feature of Cohen and Safran's diaspora definition is the sustainance of a distinctive identity "over a long period of time." This clearly applies for instance to the worldwide Jewish, Greek or Armenian diasporas, as well as to the "old" Black diaspora in the Americas all of which have have indeed retained a "strong ... group consciousness" spanning across many generations (Cohen 1997: 26). But what about more recent diasporas, like the "new" African diasporas among which Eritreans can be counted? Are they here to stay, or will they prove to be first generation phenomena? Clearly, the conception of transnationalism, as well as the (perhaps premature?) labelling of a growing number of highly divergent transmigrant communities as diasporas "must grapple with the question of whether it extends beyond the immigrant generation" as Levitt and Waters find (2002: 3). While there has recently been some skepticism, especially from those who question the analytic value of the "transnationalist" concept, authors such as Glick-Schiller and Fouron (2002) argue in favour of a transnational definition of the term "second generation" that includes also of the migrant children's peergroup in the homeland. As a contribution to this on-going debate this paper seeks to highlight both: the emotional and practical links that bind Eritrean youth to their parent's country of origin, but also their experiences of rejection that force them to re-negotiate their sense of belonging. ${ }^{9}$

In the first part of this paper I ask, how Eritrean discourses on nationalism have been shaped by the experience of exile. And, more specifically: how has growing up in exile impacted the second generation's notion of Eritrea and their own sense of Eritreanness? The second half of this text then focusses on the meeting of diaspora and local Eritreans. In what ways are the exiles' views reshaped when meeting with the local again? What consequences arise from these meetings for the transnational links between Eritrea and the diaspora: for the exiles? for the locals? And how do these encounters between a local Eritrean culture (of war) and an Eritrean exile culture influence the ongoing internal trans/formation of the Eritrean diaspora in Germany? 


\section{Exile childhoods} been born or grown up outside Eritrea and did not know each other. A few "transnational" contacts existed among those who had already taken part in the KYCT 2000 and had kept in touch since. Some of this latter group also actively helped to advertise the 2001 trips among the holidaying youth in the Eritrean capital Asmara, e.g. by distributing flyers or just by telling anyone they met. Those who joined the tour mostly came in small groups from one particular diaspora country, or even city. During the five-day journey these "national" groups were never entirely dissolved, yet a general sense of we-ness became palpable especially when singing along to old EPLF songs everyone knew by heart. Their "performance" seemed so well coordinated and rehearsed that it created the impression of a school reunion conjuring up shared memories and experiences by singing their old tunes. The music seemed to provide a bridge between the foreign raised Eritreans, no matter where they came from. It was a rendezvous for similar childhood memories of Eritrean feast and festivals, demonstrations and meetings experienced in different places in exile. It also recreated an imagined home country that music and lyrics helped to reinforce. Music-making and other forms of popular culture served as a site for the creation of an imagined Eritrean identity. As an Eritrean youth group writes in the late 1990s about a dance performance:

Our knowledge about these dances comes mainly from the EPLF's videos and festivals which where supposed to keep up a link with the liberation struggle. Most of us grew up with those videos, they are part of our own history. (Beles 1998: 36, translation B.C.)

Before looking more closely at the situation of Eritrean children growing up in exile, however, it seems advisable to provide some more general information about Eritrean refugees in Germany, their organisations and links with home.

The first Eritreans coming to Germany were male students, workers and sailors who had arrived in the late 1960s. Over the years the increasingly repressive political situation in their home region made them exiles. Many of them applied for asylum and also became loosely organised in political groups such as Eritreans for Liberation in Europe (EFLE). The number of Eritrean asylum seekers rose sharply after "Ethiopian revolution" in 1974 and the ensuing "Red Terror" of the new military regime in Addis Ababa. Throughout the late 1970 s and 80 s, it was increasingly not only men that swelled the ranks of the Eritrean refugee community, but whole families or women with children. Most of them became members of the Eritrean exile organisations whose work was almost solely focused on supporting the struggle at home.

During the 1970s the two major Eritrean liberation movements, the Eritrean Liberation Front (ELF) and the Eritrean People's Liberation Front (EPLF) were competing for power and supporters from among the exile community. The EFLE joined ranks with the latter, and in the following years became integrated within the foreign branch system of the EPLF's mass organisations (cf. Hepner 2004). In Eritrea the ELF lost the military struggle between the fronts in 1981. Inside the field this situation provided the EPLF with the opportunity to consolidate their influence and to engage in social transformation based on Marxist-Leninist ideology. While the military wing of the ELF had dissolved, pockets of support for the ELF still remained in exile countries, but the 
mass organisations of the EPLF were by far stronger. Here I focus mainly on the EPLF, which by the mid-1980s had set up an efficient network of worldwide exile organisations.

Following the socialist trend of their time, the EPLF organised their supporters in the so-called mass organisations, consisting of (peasants',) workers', women's and students' unions. These organisational structures built in the field more or less replicated in the exile Eritrean communities. In some ways they became perhaps more successful than in Eritrea proper where the EPLF's influence was largely limited to the liberated areas, and not unanimously welcomed by a conservative peasantry (see Tronvoll 1998). In exile, the mass organisations supported the social and nationalist revolution, but also provided services, a link with home and an opportunity for Eritrean socialization. In the mid-1980s a great majority of Eritrean refugees was thus organised with the EPLF, making it one of the most efficiently run national liberation movements worldwide. Even the few formally independent Eritrean relief, self-help and professional agencies were mostly personally and structurally linked to the party. This effective bundling of forces and resources was not only achieved by appealing to the refugees' undoubtedly strong sense of loyalty and dedication, but also by the systematic use of control mechanisms and coercion (cf. Pool 2001, Hepner 2003, Conrad 2005, Woldemichael 2005).

With the new refugee families arriving and others establishing families in the $1980 \mathrm{~s}$ came the need to accommodate the growing young generation. The Eritrean nationbuilding project was competing with the host society for the loyalty of the children, because: "... children ... are the flowers of our revolution, and the harbingers of our future society," Matzke (2003: 172, citing an EPLF report from 1982). In Germany, members of the National Union of Eritrean Students (NUES) coordinated a children's group, the "Red Flowers". It was named after a children's cultural troupe that had been formed in the EPLF liberated zones of Eritrea in the late 1970s. The original "Red Flowers" toured villages and refugee camps performing traditional and revolutionary songs as well as "short didactic sketches on education, illiteracy, and ... dances" (ibid. 2003: 173). The diaspora "Red Flowers" also sang revolutionary songs and staged short plays at EPLF meetings and major Eritrean holidays. ${ }^{10}$ Yet, while the original "Red Flowers" epitomised the vision of a new revolutionised Eritrea, the exile youth groups also had another function ${ }^{11}$ : It was here that children learned the basics of their mother tongue and the unique Ge'ez script, and were also given some ideas about their country, society and culture. Yet, as many elements of "traditional" Eritrean culture(s) and society(ies) were scorned by the EPLF as feudal, reactionary and in need of reform, the Eritrea narrated here consisted of highly selective images designed to inculcate exile youth (and adults) with the EPLF's vision for country and society. Lacking a reference frame or first hand experience from the home "culture" the youth's image of their home was formed by these EPLF narratives, which sometimes were contradictory and blended a traditional past with a utopian future.

21 Also within the families the image of Eritrea was reproduced in a selective fashion highlighting some values and cultural practises, while suppressing others. Yet, hoping for an eventual return home, most Eritrean parents try to socialize their children according to the Eritrean "values". Apart from trying to impose the dos and don'ts of their home society, the parents also narrated Eritrean history and genealogy to their offspring. It's important to mention here, however, that some if this narrated history 
and memory was revised and influenced by the political indoctrination of the EPLF mass organisation. This often led to a distorted picture. Officially, for example, awareness of ethnic origins, religious differences were denounced as divisive and "bad." Privately however, they continued to be important, for instance when choosing a marriage partner. Another example is the EPLF's campaign for women's equality that stood in stark contrast to the attempts of many refugee families to raise their daughters to become demure and obedient housekeepers and to uphold a patriarchal tradition in a "libertarian," "western" environment. ${ }^{12}$

Being in its core an "anti-establishment" youth movement, the EPLF drew strongly on the mobilization of young men and women who joined the movement not exclusively for patriotic reasons, but also because it provided a chance to escape from traditional constraints and hierarchies (cf. Tronvoll 1998, Quehl 2002). In other words, like any revolutionary movement, the EPLF was a destroyer of tradition and the societal order of old. In the exile countries, however, (traditional) culture and values gained new importance as a means of re-ascertaining one's identity. Exile organisations thus had to embark on a tightrope walk between being keepers of a tradition they partly renounced, yet had to draw on for reasons of mobilising, uniting and maintaining an identification of the refugees with their culture and country of origin.

Despite looking like a patchwork quilt with many gaping holes in it, the narrated image of Eritrea provided young exiles with a strong sense of patriotic pride and belonging that offered protection against the ignorance and insults they invariably experienced as an African minority in Germany. Stories about Eritrean heroism as well as the wrongdoings the Eritrean people had suffered yet not succumbed to, doubtlessly helped the younger generation to face a foreign, often discriminatory, and widely indifferent environment, and to give meaning to individually felt hardship. Most of all, however, the narratives, that were almost invariably presented from a "we" perspective (cf. Nolting 2002, Matsuoka and Sorenson 2005) allowed also foreign-born or - raised Eritreans to put themselves into one line with past and present Eritreans fighting for their country's independence, as well as for recognition, dignity and social justice.

24 This conjuring up of an "imagined community" (Anderson 1992) was further strengthened by the lived solidarity with Eritreans at home and among the exiles. The children attended political, cultural and social gatherings together with their parents, helped with street collections, the organisation of demonstrations and charity events, but were also engaged in an elaborate network of mutual support. Individual families had, albeit to varying degrees, contacts with their families left in Eritrea or living in Sudanese refugee camps. The sense of obligation and responsibility towards their relatives and their country contributed to making Eritreans less prone to adopting the image of the helpless, homeless, uprooted refugee. They not only helped to further the cause of the Eritrean struggle financially and morally, but always felt and acted as active, integral part of the Eritrean national movement. Apart from a continued willingness to make financial contributions this is also manifested in their readiness to act as ambassadors of their proud (proto-)nation. Until today, the question: "Where do you originally come from?" prompts diaspora Eritreans of all ages to embark on a lengthy (and always very similar) account of their country's history. Structure, vocabulary and vantage point of these narratives identify them unmistakably as products of the EPLF's nation-building efforts. 
strong focus on Eritrea thus boosted the refugee's self-esteem and empowered them to move successfully in their host society. But the prioritisation of supporting the struggle also had its downsides, especially for the upbringing of the 1.5 and second generation. Being often entirely consumed by the on-goings in Eritrea and in their organisations, parents erroneously assumed that return to Eritrea would one day end their life in exile and make integration into and deeper understanding of the host society unnecessary. Political and social activities drained most of the refugees' energy as well as their financial and emotional resources. Membership in the EPLF (or ELF) mass organisations meant to take part in regular, sometimes daily meetings that reduced time for family life, careers or focussing attention on the children's education:

...as all Eritrean citizens love their family and country all [their] mind and thoughts were to help [their] family and country during the ... struggle. Although it cannot be said that [the families] forgot their children ... they did not give care to them as required... Moreover, most had the unstudied ambition: 'once the liberation of the country is achieved, I will go to my country taking my children! (Abraham Tekle 2001: 38)

The following quotation highlights the extent to which life in exile was directed towards past and future Eritrea, rather than taking place in a here and now. Eritrean author Abeba Tesfagiorgis recalls:

...it was undeniable that I had been preoccupied all those years with the welfare of Ruth and Tamar [elder daughters who had become fighters], my family [those left behind], my country. I had tried to make true Eritreans of my [younger] daughters within a strong American environment. Was I really right in doing so? ... It was Muzit's first tennis lesson and she wanted her parents to be there. We were there in body, but where was my heart? And what year was it? Why did I not take a photograph? (Abeba 1992: 208; emphasis as in original)

Abeba's quote illustrates that life in exile was - understandably - perceived as provisional and incomplete. Many families had been broken up by the war. In Germany a large number of Eritrean women arrived in the 1980s without their husbands or, like Ababa, accompanied by only some of their children. Others had had to stay behind for various reasons, had joined the EPLF, or worse, were imprisoned. In other cases, the children were sent abroad on their own. Especially among the 1.5 generation there are quite a substantial number of "unaccompanied child refugees" who grew up in German children's homes or foster families. ${ }^{13}$

Thus the varying living conditions, family status, the parents' political affiliation, their education and understanding of their children's situation have it that the second generations' knowledge about Eritrean culture and history, the cause of their exile and extent of their transnational contacts may vary enormously. Moreover, children were more exposed to German culture and society had, in accordance with their age and experiences, other interests besides their parent's home country. The constant reference to Eritrea seemed at times tiresome to them or even provoked resentment: "Eritrea for breakfast, Eritrea for lunch and Eritrea for supper," Nolting (2002: 65, translation B.C.) quotes a young Eritrean woman, reflecting on her parent's preoccupation with Eritrea. Similarly, many of my interviewees also expressed the feeling of having to compete with a far-off country and unknown relatives for their parent's attention.

For some of the second generation "Eritrean-ness" is reduced to a few stereotypes and political slogans completed by a set of arbitrarily selected customs and cultural practices and the love of Eritrean food and music (cf. Brixius and Tewes 1992: 39;

Revue européenne des migrations internationales, vol. 22 - $n^{\circ} 1$ | 2006 
Lehrerkooperative 1994: 10). Then again you find others having a remarkably detailed and critical knowledge about the country's history and culture(s). For the great majority of young Eritreans that I met something in between seems to ring true. Being formed through narratives strongly tinged by the party's nationalist ideology and their parent's nostalgia, their image of Eritrea seemed like a collage combining pictures of a paradise lost and a future utopia. ${ }^{14}$ Moreover, while Eritrean nationalism within the country had a largely inclusive character aiming at moulding people of different denominations, ethnic and regional groups into one nation, the Eritrean exile's longdistance nationalism, inevitably contained a strong element of exclusiveness, too. As a tiny minority in danger of getting "lost" in their host-society, nationalism provided them with a tool to preserve a separate identity both as a group and as individuals (see also Sorenson 1991).

\section{Breakdowns and new beginnings}

30 With Eritrea's formal independence came the chance of realizing the "return" plans that had occupied the dreams of Eritrean exiles for so long. In Germany a governmentsponsored remigration programme (Fachkräfte Programm; FKP-Eritrea) provided some financial support for Eritrean professionals seeking to re-establish themselves in the homeland. Yet despite this possibility and the widespread wish to return, only a minority eventually did so. Most of the re-migrants were men, and more often than not their families remained in Germany. ${ }^{15}$ Asides from job and housing problems it was fore-mostly the concern for their children that led the majority to postpone repatriation for an undefined period of time. But even until such a preliminary answer to the return question was found, months and years would elapse. And gradually and almost imperceptibly temporary asylum became permanent sojourn.

Especially the two-year period between liberation and independence was fraught with uncertainties and changes. Not only in regard to Eritrea's development and the return question, but also regarding the continued stay abroad. With the de facto end of exile, the relationship to both home and host country was to be redefined - formally as well as mentally. For one thing, Eritrean refugees in Germany had officially been registered as Ethiopians. Now, surprisingly, many of them applied for German citizenship (rather than Eritrean). One reason simply was that many refugees only now fulfilled the requirements for naturalization in Germany. Another, that travelling to Eritrea as an asylum seeker was risky. Visiting the country you purportedly had had to flee could lead to being denied re-entry to Germany. More generally, possessing a German passport gave many exiles "just-in-case" sense of security.

At the same time, however, liberation brought within grasp what Eritreans at home and abroad had fought for during all these years: the formal acknowledgement of their national identity as Eritreans. The final hurdle was the UN-supervised referendum, taking place in spring 1993. Eritreans abroad could also cast their votes. Yet, the registration for the referendum also laid the groundwork for the creation of a transnational Eritrean state seeking include and control its citizens abroad (cf. Bernal 2004, Hepner 2004, 2005). The blue registration card was later used an identity card, known as menenet ("identity"). For diaspora Eritreans (even for those with e.g. German citizenship) it also serves as a visa waiver. Another step was the issuing of an Eritrean citizenship decree and, soon thereafter, the introduction of a "reconstruction" tax that 
was later transformed into a "diaspora" tax. ${ }^{16}$ This "tax" is collected by the Eritrean representations abroad and channelled to Eritrea's Foreign Office. In turns, Asmara issues a clearance without which it is impossible to conduct official business in Eritrea be it claiming an inheritance or getting documents needed for marriage (cf. Al-Ali et al. 2001).

These crucial changes in formal status officially signified the end of exile. But the postindependence years were also a watershed in terms of exile organisation. The mass organisations were dissolved together with their mother organisations in Eritrea. ${ }^{17}$ With independence realized these supportive structures seemed to have become obsolete to the Eritrean leadership. The dilemma in the diaspora was that the mass organisations had not only provided support for the struggle but also formed the core of the exile community. Without them and their subgroups (e.g. the "Red Flowers") a whole array of services and activities virtually disappeared overnight or became paralysed, as they had been directed from Eritrea.

The resultant slackening of political engagement and mutual help has generally been bemoaned, though that certainly involves a fair amount of nostalgia. It was mostly it was only in hindsight that the dissolving of the mass organisations came to be seen as a loss or a "breakdown" of community structures. ${ }^{18}$ In general people were preoccupied with private matters. And although the exile organisations had often been described as "a big family," there was now a chance for Eritrean exiles to reconnect with their real family and friends in Eritrea and in the worldwide diaspora. Re-establishing old circuits of sociability was facilitated once Eritreans were naturalized or received a permanent residence status. Family reunions, marriages (especially between diaspora men and women from Eritrea), but also an increase in family break-ups dominated the diaspora's post-independence life. ${ }^{19} \mathrm{~A}$ substantial number of new arrivals too, who did not know the days of exile, contributed to changing the community's face. The spirit of solidarity amongst exile Eritreans of all walks of life had been grounded fore-mostly in their common desire for independent nationhood. With that aim fulfilled it was now possible to socialize with people of your choice again.

On the whole the years between 1991 and 1994 saw contradictory developments: on an official level a formalisation, institutionalisation and bureaucratisation of links between the diaspora and Eritrea took place. On the other hand, the social networks within the diaspora and with home became more "privatised" and decentralised. ${ }^{20}$ The emergence of the internet seemed to further contribute to the creation of stronger horizontal links within the diaspora (Eritrea proper only went on-line in late 2000). Also politically the diaspora slowly began to emancipate itself from the status of a mere foreign branch. Especially the more educated segments of diaspora society developed their own visions and ideas about Eritrean nation and state building - not always to the liking of the home regime. From the mid-1990s the Eritrean government thus began to make some effort to regain control over the diaspora's resources and activities. It began to dawn on both community leaders abroad and the Eritrean political leadership at home that linking individual diaspora Eritreans with the state was not enough to sustain a lasting connection beyond the immigrant generation or even to secure the diaspora's immediate political and financial support. ${ }^{21}$ Thus Eritrean representatives and PFDJ cadres sought to rebuild and reshape the community organisations abroad including the revival of youth groups - and drawing them more tightly into the Eritrean transnation (see Hepner 2003; Conrad 2005). 

had very little exposure to transnational Eritrean politics. According to Schröder (1992: 29) about a third of the Eritrean population in Germany was less than 16 years of age when independence arrived. Those who had been pre-adolescents at that time (and thus too young to be seriously involved), where now teens. By the mid-1990s there was a whole generation that had been entirely raised in Germany. Having been exposed to the German education system and mainstream culture they had also adopted cultural and moral values that differ from those of their parents. Not surprisingly this led to conflicts within the families (Berhe 1999: 42). Also community events and meetings which used to provide room for socialising and learning about the situation in Eritrea took place less frequently than in the 1980s. Besides, most teenagers felt out of place there. The elder generation's problems discussed there were not theirs, the constant talk about the developments in Eritrea led some youngsters to say: "What's that to do with us?" or "Who cares about our problems?" - reflecting their parent's continued preoccupation with Eritrea. Often the youth also interpreted efforts to get them involved as yet another attempt of their parents' to keep them under control.

Still, even in the in-between years from 1993 to 1998 there were various attempts to organise Eritrean youth in Germany and keep them connected to their country. For one thing there were several football Eritrean teams scattered all over Germany that usually also had a youth team. The MahberKoms, though to varying degrees continued to provide Tigrinya lessons. So did some of the Eritrean religious communities that gradually became more influential as the dominant political organisations had broken away. German social workers as well as Eritrean-German friendship societies that had emerged out of earlier solidarity movements also provided for Eritrean refugee children, especially for the relatively large number of unaccompanied youth that had arrived only in the late 1980s. In Frankfurt a German teachers' association (with the help of Eritrean students) ran the "Eri-Treff", providing free tuition and leisure time activities for Eritrean pupils and their friends. In 1993 they organised a trip to Eritrea. Another Eritreo-German project in Berlin, the "Workcamp Eritrea" was started in 1994. It organised for Eritrean and German youth to co-operate with young local Eritreans on an international summer project to plant trees in Eritrea.

It was out of such groups that further initiatives developed. The Berlin-based German language magazine "Selam Eritrea" (1995- 2001) was one example. But also "Eritreans only" groups emerged out of this environment. Perhaps not coincidentally, some youth who had taken part in the Eri-Treff trip in 1993, became members of Beles- Young Eritrean European, Beles, founded by Eritrean pupils and students in Frankfurt in 1997, focussed strongly on questions of identity. Around the same time at least other groups, "Da'aro" and "Mogogo," with partly overlapping membership came into being in Frankfurt which is home to the largest Eritrean community in Germany. ${ }^{22}$ However, all of them were, for various reasons, rather short-lived.

According to one of the former leading cadres of the NUES (later renamed Eritrean National Union of Youth and Students - NUEYS) Germany, he and some others had privately and as early as 1993 tried to informally get people from the old NUES back together. One group resulting from these efforts is still active, but can hardly be labelled a "youth group", as most members are well above thirty. The official also said they experimented with bringing Eritrean youth into then still existing GermanEritrean friendship societies, hoping this would be a more suitable environment to get 
them interested in engaging themselves for their home country. ${ }^{23}$ Until the outbreak of the borderwar with Ethiopia, however, it seems that the success of such endeavours had only been modest.

Most youth groups existing today were only started between 1998 and 2000 under the impression of the war with Ethiopia. They were often initiated by Eritrean college and university students. And at least the founding of the Warsay ${ }^{24}$ movement in Frankfurt, which came to be the largest and most influential group, was also the result of the joint-mobilization efforts by the PFDJ (the Eritrean ruling party), the local MahbereKom and the Eritrean diplomatic misson in Germany. Local students felt addressed by the Consulate General's appeal to their solidarity. They initiated a movement aimed at organising the youth in and around Frankfurt. But although the first impulse had come from "above", the Warsay movement's involvement was nonetheless rooted in the deep-felt wish to do something for Eritrea and not to remain mere on-lookers of war and the ensuing humanitarian crisis. In its heydays this mostly local group of youngsters counted about 500 members of diverse backgrounds and ages from 14 to 30 plus who cooperated in very engaged and disciplined manner reminiscent of the days prior to independence. Warsay marched in protest against the war, invited experts to speak about the current situation and organised parties to raise funds that were sent to Eritrea. A "financial," "social," and "info task force" were established..$^{25}$ The latter also created a website and e-groupthatattracted members from all over Germany who joined the often very patriotic debate about the situation "at home."

41 Apart from Warsay Frankfurt some 20 youth groups were founded throughout Germany during the war, persuing similar aims. In 1999 an umbrella organisation for Eritrean youth groups was created; again a former NUEYS cadre and embassy employee encouraged and coordinated this effort. The first difficulty had been to get in touch with all the existing groups as there was no "central institution" with which they were registered, even though the Eritrean Embassy in Berlin as well as the Consulate in Frankfurt make efforts to establish links with all sorts of Eritrean diaspora organisations. When the first umbrella organisation held its second meeting, several members complained that the term "umbrella organisation" smacked too much of control and hierarchies. It was then renamed Forum of Eritrean Youth Organisations (FEYO), and eventally a structure based on regional and topical committees (still reminding very much of the mass organisation's structures) was set up. Between 1999 and 2003 a number of meetings, joint events and projects were organised. Among the most successful of them were sports - or cultural events such as the annual Youth Festival. But FEYO also actively sought contact with the NUEYS in Eritrea. At a FEYO meeting in autumn 2000, a member reported about her work experience with a ministry in Eritrea and her participation in the "Know-Your-Country-Tour" that had taken place in summer 1999 despite the ongoing war at the border. It had even included a tour to the front and to the military training camp Sawa. The report was received enthusiastically by the young activists, and indeed I was to meet at least half a dozen of them on the 2001 tour.

\section{Strange encounters and lost illusions}

But not all of the younger generation that visit Eritrea do so out of their own initiative or with the same enthusiasm shown at the FEYO meeting. And even if they wanted to 
join their parents on a trip "home", many saw themselves enjoying beach life at the shores of the Red Sea rather than being dragged from one house to the next to be presented to an extended family. Not surprisingly, most youngsters eventually coming face to face with Eritrea (often for the first time) find it difficult to recognise the place as the Eritrea of their imagination. Especially teenagers, being not always firm in Tigrinya, are quickly bored by the daily routine of visits and have to be bribed into Sunday behaviour by allowing them to roam the streets of Asmara after nightfall. Here they are likely to bump into like-minded youngsters from their own or other countries of resettlement. Walking along Liberation Avenue and its busy side streets in the late afternoon and evening you cannot fail to notice groups of diaspora teenagers monopolizing certain meeting places, street corners, bars and restaurants, some of which are obviously tailored to suit their "western tastes". The same goes for a handful of nightclubs catering mainly for exiles, tourists and foreign experts - not only in regards to decoration, food and drink, but also when it comes to entrance fees and prices. Still low by western standards they are yet beyond anything most locals can afford (cf. Treiber 2005).

Whilst an Eritrean newspaper commented benevolently on the Babylonian mix of languages one will hear in Asmara during the rainy season (Eritrea Profile, 18 August 2001: 8), locals - and in particular the youth - seem less amused by these cosmopolitan graces. With a mixture of envy and scorn they view their "cousins" from abroad who hang around displaying their branded clothes, spending money and paying them little or no heed. There have been reports of tensions between exiles and locals virtually from the beginning of the annual pilgrimages in the mid-1990s (cf. Lehrerkooperative 1994; Hartman 1998). Others denied that there were any problems or put them aside as childish squabbles. However, during my sojourn in summer 2001, there was no pretending that all was fine between exiles and locals. One year after the end of the Ethio-Eritrean border war (1998-2000) the families of those killed had not been notified and were anguishly awaiting news from the front. In this situation the happy-go-lucky lifestyle of some young Eritreans from abroad provoked considerable resentment. Also, the regular fights between local youngsters and diaspora youth could no longer be brushed aside as "normal" in-fights between teenagers. The lines of conflict were neatly drawn between "us - the Eritreans from abroad" and "them - the locals".

The nicknaming of the exiles as beles might illustrates this. Beles is the Tigrinya name for the prickly pear. Its sweet, but tough and thorny-skinned fruits are harvested during the rainy season when the diaspora Eritreans come to visit. An explanation I have been offered for this nicknaming gave it a more metaphorical meaning: "The exiles are like beles, they are only here for a short time bringing a promise of sweetness. But when they are gone you are just left with a pile of rubbish" ${ }^{26}$. In any case, calling someone beles is meant to be an insult and also understood as such. Some of the exiles retaliated by calling the locals kiraf beles- beles skin - alluding to the local youth's endeavours to imitate their western habitus and fashion style.

After our return to Asmara the Know-Your-Country-Tour travellers participated in a NUEYS organised panel discussion between local and diaspora youth. Both sides blame each other for the lack of communication and the frequent violent incidents. Local youngsters accused the diaspora youth of being arrogant show-offs with a lack of regard for Eritrean culture and tradition. They also made them responsible for rising taxi fares and restaurant bills. Older Eritreans pointed a finger at diaspora parents for 
giving their offspring not enough information about local sensitivities. In particular they bemoaned the behaviour of girls from abroad, who smoke in public, talk "disrespectfully" to their elders and dress in fashion that is considered indecent. The diaspora girls on the other hand complained of being verbally and physically harassed by locals. In private conversations Eritreans from abroad often voiced the opinion that envy, rooted in the economic inequality between the diaspora and Eritrea, was the main source of conflict. Yet, different behaviours and standards of living are only the visible expressions of an unacknowledged alienation between what I have termed "culture of war" and "culture of exile". All rhetoric of (trans)national unity notwithstanding, the image of Eritrea and Eritrean-ness is not the same in Asmara and Adi Frankfurt ${ }^{27}$. Especially for younger people, whose knowledge about "home" is handed down by their elder's and the liberation movements' selective narratives, it is difficult to distinguish what is "Eritrean exile culture" and what is locally "lived" culture. An anecdotal incident may illustrate this.

In a cafe a group of teens from Italy questioned me about what I thought of Eritrea. Every favourable answer, however, spurred them into even louder complaints. Having covered the weather, the boredom, the state of hotels and toilets, we turned to the local cuisine. Finally one boy exclaimed exasperatedly: "But they cannot even make proper injera (a flat spongy bread eaten with most meals in Eritrea)! It's all dark here. In Italy, we make it nice and light in colour". In fact, the light-coloured injera you often get abroad is the result of using corn- and wheat meal as a substitute for the local teff. What's very telling, however, is the lopsided view of what is "authentic" Eritrean culture. For the kids diaspora culture is true Eritrean culture, whereas local Eritrean culture is just a bad try. And what goes for food also rings true for less material ideas about Eritrean-ness.

Another not unusual story is that of a German Eritrean who is shocked at her relatives' consumerism. Brought up on stories about Eritrean virtues and values such as selfreliance and industriousness, she had expected her cousin in Asmara to invest the money she gave to her, but found her relative had spent it on fashion items instead. Local Eritreans on the other hand tend to believe that living in "the West" automatically means being rich. How difficult it is to make a living abroad is not grasped, and less so, as many overseas Eritreans like to gloss over the downsides of their diaspora lives. In order to prove their success and ease a guilty conscience, gifts are made which sometimes financially ruin diaspora families for the rest of the year or longer. Consequently both sides feel misunderstood. The exiles feel their efforts are not fully appreciated while their relatives think them both arrogant and unwilling to do more for their poorer relations.

The obvious estrangement of the young generation is also seen with concern on the side of the Eritrean authorities. Depending on the diaspora's hard currency remittances, the government has started some initiatives to encourage continued solidarity (and cash flow) from the second generation ${ }^{28}$. The "Know-Your-CountryTour" organised by the National Union of Youth and Students (NUEYS) is but one example of trying to keep the second generation "in touch" with their place of origin. Yet, as experiences narrated in the first part of this paper above show, the results of this endeavour can at best be called ambiguous. Other attempts at integrating diaspora youth more firmly within the Eritrean transnational field - such as a programme 
offering internships with the Eritrean administration - also proved to be potentially alienating experiences

Young Eritreans from abroad coming to Eritrea as interns, volunteers, or to collect material for academic studies, are mostly well in their twenties. Many of them still used to be members of the "Red Flowers" as children or were later active in Eritrean youth association, campaigning for Eritrea during the 1998-2000 war, or had chosen an "Eritrean" for their graduate papers. The majority of them represent the more educated segment of diaspora society. And as students or young professionals they also tend to be successful and "well-integrated" in their country of resettlement. Apart from "searching for their roots" and gaining work and life experience, most of these young people also wanted a chance to become acquainted with an Eritrea out of beles season, outside family homes and beyond prearranged trips to the Red Sea in airconditioned Toyotas.

Still, even though this group makes much more of an effort to adapt, personal experiences vary enormously. A NUEYS official who facilitated these internships reported that while some were happy and planned to come back; others had vowed they would not even return for a holiday. Rahwa, a young woman I met in Asmara had just left a volunteer job after being told by an Eritrean colleague that she was not a "real Eritrean" after all. The incident also led her to contemplate about her future:

I used to think some day I would go to live in Eritrea, perhaps with 30 or 40. It was always in the back of my mind. Now I cannot even imagine going back with 60. [Pause] But neither can I imagine growing old in Germany. I feel quite homeless now - like a Kurd. (Fieldnotes, B.C.)

51 She was referring not only to her personal disappointments, but also felt that the Eritrea she had come to know did not have the bright future she used to imagine, but was sliding into authoritarian rule: "Even in 50 years there will be no democracy here," she said in late August 2001. Less than a month from then political dissidents and journalists were arrested and private newspapers banned. And with the situation in the country growing increasingly tense, the diaspora (youth), too, became fragmented and paralysed.

\section{From myth of return to myth of origin: reinventing the diaspora}

52 By and large official as well as private "Know-Your-Country" experiences lead to some disillusionment among Eritrean diaspora youth, and force them to re-negotiate what it means to declare "I am Eritrean". Unsurprisingly, the "real," present day Eritrea diverges from the images the youth had created based on their parents' and the exile organisations narratives. All nationalist "hade hizbi, hade libi" - rhetoric notwithstanding, only few of the young travellers felt fully part of Eritrean society. ${ }^{29}$ Far from solving the question of belonging, these transnational journeys often complicate them. Before coming to Eritrea, the feeling of not being totally at home - or being marginalised - in Germany was made more bearable by seeking refuge in the thought that one's "true home" was elsewhere. Encountering similar alienation and rejection in Eritrea, any however vague idea of "return" no longer seems to provide a realistic point of refuge from, or an alternative to life in the diaspora. 

as one of the "Know-Your-Country Tourer" suggested? Feeling both German and Eritrean $^{30}$ - or neither? The initial reaction is indeed not rarely one of expressing disorientation and feeling "quite homeless," as Rahwa put it. Other young people I interviewed emphasised their German-ness. Yet most of them remained aware that their problem of belonging will not be solved by "simply" adopting a (for instance) German identity either - no matter how much they have internalized values and ideas of their resettlement country. It must also be noted that these immediate evaluations where often revised after returning to Germany, and might be revised again as individual and external circumstances change. Something that remained was a stronger feeling of we-ness among the diaspora youth as a group of Eritreans apart from their compatriots within the country.

presenting the findings of my research in Eritrea to an audience of mostly young Eritreans in Germany, I tentatively titled my presentation “The 'Beles'- A Tenth Ethnic Group?" I added it was meant somewhat provocatively. During the discussion a young man said: "Actually, your title is not provocative at all. It's the truth!" Some of the older listeners flinched, but the younger ones nodded or at least did not contradict the speaker. As the sojourns in Eritrea have shown, the "culture of exile" not only set them apart from Eritrean society but serves also to create a sense of solidarity and mutual understanding among fellow exiles from all over the world. This also explains why most young people go back to Eritrea for another holiday in spite of negative experiences. As a young woman from Frankfurt put it:

They [the locals] gave us a hard time, but still I feel quite homesick now, not for the Eritreans there, but for the friends I made there. I mean other Eritreans from abroad. In Asmara even people you hardly say hello to in Frankfurt are suddenly your best buddies. (Fieldnotes B.C.)

argue that journeys to Eritrea make most youngsters aware that something like an Eritrean "exile" or "diaspora culture" in its own right exists at all, and that it might be something of an asset, rather than a stigma. But as any other diaspora, the Eritrean diaspora cannot exist without a common point of reference: and this remains Eritrea. But rather than the myth of return, it is now the reference to a common origin that makes Eritreans abroad a community. Thus the summer holiday is no longer seen as a rehearsal for a potential return, but more like a celebration of one's origin and community. Like an Eritrean version of the Jewish diaspora's "Next year in Jerusalem," the pilgrimage to Eritrea has become a part of diapora culture; maybe even a rite de passage for the youth from abroad. In any case there is a growing realisation that inspite of the existence of a wider transnational field that embraces both Eritrea and its diaspora, there is also a "here" and "there"; a "culture of war" and a "culture of exile." In an article published in the Eritrean-German magazine "Selam Eritrea" in 1998, the youth group Beles very articulately embark on a discourse on identity, reflecting such experiences:

Parallel to Eritrean society an exile society is developing whose young generation is closely historically linked to the war and the country, but sometimes feels ... that their country of origin is a strange place to them. Beles is the attempt to overcome this feeling of alienation ... by acknowledging the social reality of exile and thus finding a new way of seeing ourselves as Eritreans. Beles is a fruit that grows during the rainy season in the highlands of Eritrea. About this time also most of the Eritrean exiles arrive in Eritrea... Hence the local Eritreans named them "beles". The youth group "Beles- Young Eritrean Europeans" has adopted this name in order to build a bridge between Africa and Europe. What is usually considered to be 
two mutually exclusive places (Africa and Europe) comes together in "beles" - a "life in between" ... Our mother tongue, the feeling of home, the relationship to our parents are no longer easy to define. To explain contradictions which are none is our aim and this will make us capable of living in exile. (Beles 1998: 36/37, translation B.C.)

The Eritrean diasporic youth, while still having a sense of looking back to the homeland maybe on their way to an articulation of a new culture and mode of survival. To focus (as Beles did) on a "life in between" my also help them to re-define their rather mythical relationship with their country of origin. Further travels and activities in and on behalf of Eritrea are undertaken no longer under the illusion that all Eritreans are "one people," but from a distinct exile perspective, that makes it possible to relate to Eritrea in new ways:

...we have noticed that the connection to our Eritrean culture of origin is not either there or not, but exists on different levels and is continually a-changing ... But although our relationship with Eritrea is characterised by alienation, it still exists. Eritrea is part of our life - only in a different way. (Beles 1998: 36, translation B.C.)

\section{Oulook: a transnational second generation?}

57 I have so far described the encounters between young local Eritreans and diasporaEritreans and their consequences mainly from the latter's perspective. But the contact between both groups also impacts the lives and identities of the local youth, especially so in Asmara. In spite of the negative feelings vis-à-vis the beles, contact with them clearly changes and shapes the locals' perception of self and their ideas about the world outside. Similar observations have been made my Glick-Schiller and Fouron (2001: 175-177) who conclude that we need an extended concept of a transnational second generation that includes both young people in the diaspora and their cohort in the homeland.

It can indeed not be denied that the massive presence of diaspora Eritreans in Asmara (and other transnational contacts) have left a mark on urban youth culture in Eritrea. The encounters accelerate changes in the patterns of consumption and put pressure on youngsters in Asmara to conform for instance to certain standards of clothing set by the exiles. Wanting to adopt the exiles' more liberal lifestyle aggravates generation, social and gender conflicts. More importantly, with war, militarization, economic depression, growing political tensions and the deteriorating human rights situation there is little prospect for building a future within the country. Even mere survival is precarious. As the apparently well-off diaspora Eritreans seem to prove that you can "make it" abroad, migration seems the best coping strategy. The thin strata of educated young Eritreans are leaving the country in droves causing a severe brain drain. According to the UNHCR there almost 10,000 Eritrean youth in one Ethiopian refugee camp, mostly waiting to migrate on towards "the West", other cross the Sudanese border and embark on a costly and dangerous journey to Libya and from there on to Malta or Italy. Also, most of the 600 Eritrean Students in South Africa, will hardly not return to. ${ }^{31}$

While only few of the students manage to leave the country legally or even equipped with scholarships, the majority of those willing to emigrate will turn to their often financially strained exile relatives for help. This is but one reason why these recent emigrants are often confronted with the hostility in the diaspora. Also, their migration seems like a slap in face of the die-hard EPLF supporters who refuse to acknowledge 
that today's Eritreans have in fact any reason to flee or immigrate. Regarded as deserters or even traitors, the newcomers are not easily integrated. Rather, the conflict between a "culture of war" and a "culture of exile" emerges again, only in a different setting and an opposite constellation. But of course, these new refugees have again started to change the diaspora-homeland relationship.

\section{BIBLIOGRAPHY}

ABRAHAM Tekle (2000) "The Role of Parents in (Professional) Education for their Children" (Transl. from Tigrinya), Selam Eritrea No 14/15, 2001, pp. 38-39.

AL-ALI Richard BLACK and Khalid KOSER (2001) “The Limits of Transnationalism”: Bosnian and Eritrean Refugees in Europe as emerging Transnational Communities, Ethnic and Racial Studies 24 (4), pp. 378-600.

AMNESTY INTERNATIONAL (2004) Eritrea: "You Have No Right to Ask" - Government Resists Scrutiny on Human Rights, AI Index: AFR 64/003/2004

ANDALL Jacqueline (2002) Second Generation Attitude? African-Italians in Milan, Journal of Ethnic and Migration Studies, 28 (3) p. 389-408.

ANDERSON Benedict (1983), Imagined Communities, London, Verso.

ANDERSON Benedict (1992) Long-Distance Nationalism: World Capitalism and the Rise of Identity Politics, Amsterdam, Centre for Asian Studies Amsterdam.

BASCH Linda, GLICK SCHILLER Nina, and SZANTON-BLANC Cristina (1994) Nations Unbound: Transnational Projects, Postcolonial Predicaments, and Deterritorialized Nation-states, London, Routledge Press.

BELES (1998) (1998) “Beles - junge europäische Eritreer”, Selam Eritrea, No. 12, pp. 36-37.

BELES (1999) Eritrea - das ist menschliche Wärme. Umfrage unter der eritreischen Jugend, Selam Eritrea, No. 13/14, pp. 33-35.

BERHE Jonas (1999) Selbständige Jugendliche - ein Probem?, Selam Eritrea, No. 13/14, pp. 41-42.

BERNAL Victoria (2004) Eritrea Goes Global: Reflections on Nationalism in Transnational Era, Cultural Anthropology, 19 (1), pp. 3-25.

BRIXIUS Elke and Helga TEWES (1992) Zwischen den Kulturen? Eritreische Flüchtlingskinderund Jugendliche in Kassel, Unpublished paper, Gesamthochschule Kassel, Fachbereich 04.

CLAYTON Dimitria and Heike PÖRKSEN (1994) Die Rückkehr eritreischer Flüchtlinge als Fachkräfte aus Deutschland, ASA Projekt, Unpublished Research Report

COHEN Robin (1997) Global Diasporas: An Introduction, London, University College London Press.

CONRAD Bettina (2003) Eritreans in Germany: Heading from Exile to Diaspora, in E. Bruchhaus, ed., Hotspot Horn of Africa: Between Integration and Disintegration, Münster: LIT Verlag, 208 p.

CONRAD Bettina (2005) "We are the Prisoners of our Dreams:" Exit, Voice and Loyalty in the Eritrean Diaspora in Germany, The Eritrean Studies Review 4 (2), pp. 211-260. 
CONRAD Bettina (2006a) Schwere Menschenrechtsverletzungen in Eritrea, Eins Entwicklungspolitik $1-2,2006$, p. 36.

CONRAD Bettina (2006b) "We are the Warsay of Eritrea in Diaspora": Contested Images of Eritrean-ness in Cyberspace and in Real Life. In: Munzoul Assal und Leif Manger (eds.). Diasporas Within and Without Africa. Dynamism, Hetereogeneity, Variation. Uppsala. The Nordic Africa Institute, in print.

FOURON Georges E. and Nina GLICK-SCHILLER (2001) Georges Woke Up Laughing: Long-Distance Nationalism and the Search for Home, Durham/London: Duke University Press, 324 p.

HABIB Naila (1996) The Search for Home, Journal of Refugee Studies, 9 (1), pp. 96-102.

HARTMANN Rainer (1998) Eritrea: Neubeginn mit Tourismus. Ein integratives Planungs- und Entwicklungskonzept. Hamburg: Institut für Afrika-Kunde.

HEPNER Tricia Redeker (2004) Eritrea and Exile: Trans/Nationalism in the Horn of Africa and the United States. Ph.D. Dissertation, Michigan State University.

HEPNER Tricia Redeker (2005) Transnational Tegadelti: Eritreans for Liberation in North America and The Eritrean Peoples Liberation Front, The Eritrean Studies Review 5 (1), pp. 37-83

HIRT Nicole (n.d.) Young Returnees from the Diaspora to Eritrea - Problems and Prospects, Unpublished Paper.

LEHERKOOPERATIVE Bildung und Kommunikation e.V. (1994) Späte Heimatkunde. Eine Gruppenreisse nach Eritrea, Frankfurt: Lehrerkooperative Bildung und Kommunikation e.V., $33 \mathrm{p}$.

FOUAD Makki (2002) The Aporias of Radical Nationalism: Political Culture, Ideology and Democracy in Eritrea, in H. Quehl, ed. Living in Wartimes - Living in Post-Wartimes, Proceedings of an International Workshop on the Horn of Africa, held in Melsungen/ Germany, January 29-31, 1999, Felsberg: edition eins, pp. 201-226.

MATSUOKA Atsuko and John SORENSON (2001). Ghosts and Shadows: Construction of Identity and Community in an African Diaspora, Toronto, University of Toronto Press, $261 \mathrm{p}$.

MATSUOKA Atsuko and SORENSON John (2005) Ideas of North, The Eritrean Studies Review 4 (2), pp. 85-114.

MATZKE, Christine (2003) En-gendering Theatre in Eritrea: The Roles and Representations of Women in the Permorming Arts, PhD Thesis, University of Leeds, 350 p.

McSPADDEN Lucia Ann and Helene MOUSSA. 1994. "I Have a Name": The Gender Dynamics in Asylum and in Resettlement of Ethiopian and Eritrean Refugees in North America, Journal of Refugee Studies, 6 (3), pp. 203-225.

NIGISTI Awalom and YOSIEF Tecle (1997), Performance Report 1994-1997 and Activity Plan 1998, Fachkräfte Programm Eritrea, FKP-Office, Asmara, 28 p.

NOLTING Nina von (2002) Gemeinschaft im Exil: Eritreische Flüchtlinge in Frankfurt am Main, Department of Anthropology and African Studies, Working Papers No. 11, on: http://www.UniMainz.DE/ ifeas/workingpapers/Arbeitspapiere.html, 110 p.

POOL David (2001) From Guerrillas to Government: The Eritrean People's Liberation Front. Oxford and Athens, OH, James Currey, Ohio University Press, 206 p.

QUEHL Hartmut (2002) Everyday Life of a Tagadelti During the Eritrean War for Liberation 1961-1991, in H. Quehl, ed., Living in Wartimes - Living in Post-Wartimes, Proceedings of an 
International Workshop on the Horn of Africa, held in Melsungen/Germany, January 29 - 31, 1999. Felsberg: edition eins, $322 \mathrm{p}$.

RETTIG Uwe (1998) Eritreische Flüchtlinge in Deutschland. Plädoyer für eine andere Jugendpolitik Selam Eritrea, No. 11, p. 23.

SCHRÖDER Günter (1992) Eritreer in der Bundesrepublik Deutschland. Materialien zur Soziographie, Arbeitsheft, Berliner Institut für Vergleichende Sozialforschung, Berlin, Edition Parabolis, $65 \mathrm{p}$.

SCHRÖDER Günter (2004) The Eritrean Community in Germany. Materials for Quantitative Analysis, Unpublished paper presented at the workshop "Focus on Eritrea," Cologne/ Germany, September 18-19, 2004.

SIMMEL Georg (1968) Exkurs über den Fremden, in ibid., Soziologie, Berlin

SORENSON, John (1991) "Discourses on Eritrean Nationalism and Identity", Journal of Modern African Studies, 29 (2), pp. 301-317.

TEKIE Fessehatzion (2005) Eritrea's Remittance-Based Economy: Conjectures and Musings, The Eritrean Studies Journal 4 (2), pp. 165-183.

TEKLE M. Woldemikael (2005) Bridging the Divide: Muslim and Christian Eritreans in Orange County, California, The Eritrean Studies Review, 4 (2), pp. 143-164.

TOBACCO Agostino and Nicoletta POIDIMANI (2001) Bologna. Testimonianze di lotta degli eritrei esuli in europa, Edizioni Punto Rosso, $328 \mathrm{p}$.

TREIBER Magnus (2005) Der Traum vom guten Leben. Die eritreische Warsay-Generation im Asmara der zweiten Nachkriegszeit, Münster: Lit-Verlag.

TRONVOLL Kjetil. 1998. Mai Weini. A Highland Village in Eritrea, Trenton, The Red Sea Press, 309 p.

WATERS and LEVITT (2002) The Changing Face of Home. The Transnational Lives of the Second Generation, New York, Russell Sage Foundation, 408 p.

\section{NOTES}

1. While the multi-ethnic Eritrean population is almost evenly divided between Christians and Muslims, most Eritreans living in Germany are Christian Orthodox Tigrinya. The Tigrinya form the largest and most urbanised ethno-linguistic group, and though this is officially refuted, they are generally seen as dominating the country politically.

2. Until today no national elections legitimize the ruling party's governance under President Isaias Afewerki. The 1997 constitution has never been implemented, dissidents languish incommunicado in jails. Civil liberties and rule of law are suspended. In summer 2001, however, only the beginnings of this developments could be felt (cf. Conrad 2006).

3. The following account is based on my fieldnotes dating from 11/12 August 2001. All names and places of residence outside Eritrea are changed. I am very grateful to both the organisers (the National Union of Eritrean Youth and Students) and the travellers for letting me join their party on this eventful journey. Especially I want to thank Yirgalem Keleta and Huria Ogbamichael who sensitised me to many problems I might have otherwise overlooked. The story I recount here, however, is that of an outsider and may therefore not always overlap with the individual recollections of my co-travellers, though I was fortunate to get some feedback on earlier drafts of 
this paper from some of the tour-participants. Any possible misinterpretation or factual fault, however, is entirely mine.

4. Note: "ferenji" means foreigner.

5. The definition of the 1.5 generation varies significantly in the respective literature (cf. Andall 2002 for a discussion of various approaches). Like Andall I define 1.5 generation as those who came to Germany after they had started school.

6. After WW II German exiles, for example, went through a similar experience. In Oskar M. Graf's novel "Flucht ins Mittelmäßige" ("Flight into Mediocrity"), the protagonist addresses a meeting of German refugees in New York, saying: “...someone who is a political refugee and has not gone home right after the war might as well forget about it. Do you seriously believe the hungry, bombed out Germans are waiting for us to give them our wonderful directives... Our real emigration is only about to start now that the war is over. So far it has only been a period of waiting. From now on it will be something entirely different: ... the diaspora..." (Graf 1984: 35, translation and emphasis B.C.).

7. The term diaspora became "fashionable" among educated German Eritreans only a few years ago, mainly through the use of US-Eritrean websites that have been talking about "diaspora" since mid-1990s. When I give a talk to an Eritrean audience in Germany, however, the meaning of the term is always an issue, as there is no adequate Tigrinya translation for it.

8. Translation from German: B.C.

9. Aspects of integration, assimilation and discrimination that define the second generation's relationship with their "host" countries are not discussed in great detail here. The reason simply is that doing so would have extended the paper beyond reasonable length. Moreover, there exists a comparatively rich literature focussing on the integration of immigrant children into settlement society. For Eritreans (in Italy) see e.g. Andall 2002.

10. Many of the children who came to Germany had before spent some time in Sudan where they sometimes had attended EPLF-led schools. In a group discussion in autumn 2000 one young man remembered that singing nationalist tunes had figured prominently on their curriculum. From my field notes: "I still know them," he says. The others nodd in agreement. Yet, in hindsight some are critical of the ideological education and the quasi-militaristic training that went along with it. Another young man ponders how he and the other kids wanted to fight and die for Eritrea. Whenever there was a celebration to honour some distinguished fighters, they all dreamt of being in their place one day. "In a way, we were brainwashed," the speaker adds. "you know, when I later read Morton Rhues' 'The Wave,' I could totally relate."

11. It is difficult to establish how many of the second generation were members of such a group. It certainly depended on their age of arrival in German and their parents' political engagement. And of course, it was only available for those living in a town with an organised Eritrean community. However, judging from my fieldwork experience it seems that most children growing up in the 1980s have at some stage been members of such a youth group.

12. See also Matzke (2003: 236) on diaspora protest about the behaviour of the female heroine in a play by EPLF dramatist Alemseged Tesfai. A visting female fighter also noted once with amazement that Eritrean women in western exile countries seemed to be less emancipated than in the EPLF controlled areas of Eritrea. (CHECK SOURCE)

13. When families were eventually reunited, they frequently experienced problems and breakups. The long separation and the very different experiences had estranged wife and husband, or parents and children. The newcomers found the more settled part of their family changed as they had adapted to the new environment. Traditional gender roles and hierarchies were tumbled up or even reversed. (see also McSpadden and Moussa 1994). Parents had to rely on their German speaking kids to master everyday life. Wives had become the family's breadwinners. Not the least source of trouble was the use of the often meagre families resources: Whose family at home would first benefit from their hard currency? Whose brother would next be helped to flee? 
14. A German journalist and Eritrea lobbyist I interviewed told me about the reactions of exile Eritreans to the videos and pictures he had brought from the war-affected, EPLF-controlled, rural areas during the liberation struggle. His younger audience was shocked by the absence of infrastructure and the dismal living conditions they saw. They were convinced that the footage did not show any part of Eritrea, but perhaps came from neighbouring Sudan. Eritrea, the film maker was told, was not like that. It was an industrialised country, with tarmac roads, shops and factories - almost like Europe. Glick-Schiller and Fouron come to similar findings in their research on second generation Haitians in the USA: "These young adults took into their experiences ... also their parents' imagery of a beautiful Haiti that once was: ... Past becomes linked to the future. Politics and nostalgia meet in concrete organizations [and] practices..." (2001: 166).

15. The returnee programme offered two schemes that could also be combined. A returnee taking on a professional job in Eritrea would receive a part of his last German salary for two years (see Bartelt 1994: 27). Later (or right from the start) s/he could opt for a credit to start a business. The programme's 1997 performance report lists 511 returnees between 1992 and 1997, bringing with them about 300 family members (Nigisti and Yosief 1997). Similarly Schröder (2004) estimates that about 1000 Eritreans altogether returned through the programme, while another few hundred people might have returned on their own account. The specific (re-)integration problems of returnee-children have been described by Hirt (n.d.)

16. See Eritrean Profile (Electronic), vol. 1, issue 49, February 18th, 1995. The tax amounts to $2 \%$ on the net income.

17. Officially it was said that a more broad-based national movement capable of absorbing also non-EPLF members was called for to rebuild the country. Some Eritreans doubt this version and speculate that the leadership were afraid of the mass organisations providing a hotbed for new political movements or parties. In Eritrea and parts of the diaspora the mass organisations were finally re-created as "non-government" organisations in the 1990s, yet at least abroad they never reached the former levels of popular participation. In Germany only the National Union of Eritrean Women continues to run a branch. It mainly supports development projects in Eritrea.

18. Thus described in various interviews and group discussions done in the late 1990s and 2000 .

19. Interview with a former refugee counsellor who noted that after independence there was even more arguing about financial issues. Again, the major question was, whether the wife's or the husband's family should be supported. But also the question of investment and return proved to be tumbling blocks in many marriages.

20. Gradually some new groups formed in the diaspora, e.g. with the aim to support their home village, but soon met with displeasure on the side of the Eritrean government. Rather than allowing direct support for a selected project in Eritrea, the diaspora citizens were asked for financial contributions, whose redistribution on certain projects would be controlled by the government. The official reason was, that this should make sure that no group or region in Eritrea was marginalised.

21. To (re-) incorporate the first generation off the Eritrean diaspora in their transnational nation building project, the Eritrean authorities could also relatively easy take up former connections and well-known structures, such as the organisation of seminars, festivals and fundraising campaigns that were now often coordinated through the embassy. The community association, often called MahberKoms, where supposed to be strengthened and should embrace also formerly non-EPLF affiliated, or even ELF affiliated Eritreans (who had so far had separate communities).

22. A mogogo is a traditional "oven" to bake injera, a flat, spongy Eritrean bread and staple food; da'aro is the Tigrinya word for sycamore tree. Similar to the baobabs in other parts of Africa, sycamores were often used as gathering places for village assemblies. In Eritrea such assemblies are called baito and are popularly regarded as early democratic institutions. 
23. Interview in autumn 2002.

24. Warsay/warsot means "heir/s" in Tigrinya. It is however, also a term for the young soldiers in the Eritrean army that fought alongside the EPLF veterans in the 1998-2000 war.

25. The setting up of committees shows that real-life organisations and networks are still modelled on the organisational structures of the independence movements.

26. Fieldnotes summer 2001, B.C.

27. Adi means village or place; Frankfurt in Germany is nicknamed "adi" as it is home the largest Eritrean community in Germany.

28. "In no other African country are remittances as important as in Eritrea, where remittances comprise slightly less than one third (30 percent) of the GDP." (Tekie 2005: 168).

29. Slogan that came up during the 1998-2000 war with Ethiopia. It means "one people, one heart," and was used to emphasize the need of solidarity and single-mindedness amongst Eritreans

30. "...I am an Eritrean in Eritrea and a German here in Germany." one young man put it (Beles 1999: 34; translation B.C.).

31. Personal communication with a student concerned (Summer 2004). Many of the students in South Africa became politically active and challenged the Eritrean government over its grave human rights violation. For them returning home would almost certainly lead to a their arrest (cf. Amnesty International 2004).

\section{ABSTRACTS}

During a thirty-years war of independence from Ethiopia (1961-1991) almost a third of the Eritrean population left the country. This article focuses on the encounters of second-generation Eritrean exiles in Germany with their compatriots in Eritrea. The author argues that in spite of the close-knit transnational networks between Eritrea and its sizable diaspora, journeys to Eritrea reveal the gap between a culture of war and a culture of exile. Until Eritrea's independence in 1991 this gap was obscured by a strong sense of long-distance nationalism and the actual impossibility of home and exile communities coming face to face with each other. The second exile generation being brought up to identify as Eritreans abroad, often experience alienation and even rejection « at home » which forces them to renegotiate their identity and reconstruct diasporic organisations and modes of interaction with the homeland. This on-going development may also help to shed light on the more general question of the viability of transnational links beyond the immigrant generation.

Durant les trente années de guerre d'indépendance de l'Érythrée contre l'Éthiopie (1961-1991), environ un tiers de la population érythréenne a quitté son pays. Cet article porte sur la rencontre de la seconde génération d'exilés érythréens en Allemagne avec ses compatriotes vivant en Érythrée. L'auteur affirme que, en dépit des réseaux transnationaux denses entre l'Érythrée et sa diaspora assez considérable, les séjours en Érythrée révèlent le fossé entre une culture de guerre et une culture d'exil. Jusqu'à l'indépendance de l'Érythrée en 1991, ce fossé a été caché par un fort sentiment nationaliste développé à distance et par l'impossibilité des communautés érythréennes du dedans et du dehors de se trouver face à face. La seconde génération qui a été élevée comme une génération d'Érythréens de l'extérieur fait souvent l'expérience d'une aliénation et même d'un rejet «chez elle ». Aliénation et rejet qui l'obligent à renégocier son 
identité et à reconstruire les organisations diasporiques et les modes d'interaction avec le pays d'origine. Cette dynamique en cours peut aussi aider à éclaircir la question plus générale de la viabilité des liens transnationaux au-delà de la génération d'émigrants.

Durante los treinta años de la guerra de independencia de Eritrea contra Etiopia (1961-1991), alrededor de un tercio de la población de Eritrea abandonó su país. Este artículo aborda el encuentro entre la segunda generación de los eritreos exiliados en Alemania y sus compatriotas que viven en Eritrea. El autor afirma que, a pesar de las redes transnacionales densas que unen Eritrea a su considerable diáspora, las estancias en Eritrea revelan el desfase que existe entre una cultura de guerra y una cultura de exilio. Hasta la independencia de Eritrea en 1991, este desfase se camufló detrás de un fuerte sentimiento nacionalista desarrollado a distancia y de la imposibilidad de que las comunidades del interior y del exterior pudiesen encontrarse cara a cara. La segunda generación, criada como una generación de eritreos del exterior, experimenta a menudo un sentimiento de alineación e incluso de rechazo "en su propia casa". Alineación y rechazo que obligan a renegociar su identidad y a reconstruir la organización de la diáspora y los modos de interacción con el país de origen. Esta dinámica también puede ayudar a esclarecer la cuestión más general de la viabilidad de los lazos transnacionales más allá de la generación de emigrantes.

\section{INDEX}

Geographical index: Allemagne

Mots-clés: Erythréens, générations issues de l'immigration, identité ethnique, jeunes, relations avec le pays d'origine

\section{AUTHOR}

\section{BETTINA CONRAD}

Institute for Political Science, University of Hamburg. 